\title{
PERANCANGAN APLIKASI KREDIT POIN PESERTA DIDIK TERHADAP PELANGGARAN PERATURAN SEKOLAH MENGGUNAKAN SMS GATEWAY
}

\author{
Muhammad Saidi Rahman ${ }^{1)}$, Hoiriyah ${ }^{2)}$ Lilis Anggraini ${ }^{3)}$ \\ ${ }^{1)}$ Fakultas Teknologi Informasi, Universitas Islam Kalimantan Muhammad Arsyad Al Banjari Banjarmasin \\ m.saidi.rahman@gmail.com \\ 2) Fakultas Teknologi Informasi, Universitas Islam Kalimantan Muhammad Arsyad Al Banjari Banjarmasin \\ ihaybjm18@gmail.com \\ ${ }^{3)}$ Fakultas Teknologi Informasi, Universitas Islam Kalimantan Muhammad Arsyad Al Banjari Banjarmasin \\ lilis.anggraini0205@gmail.com
}

\begin{abstract}
Abstrak
Madrasah Aliyah Negeri 2 Barito Kuala adalah salah satu sekolah yang memiliki visi untuk menjadikan peserta didik yang beriman dan bertaqwa, berprestasi dan mandiri. Tentu untuk tercapainya visi sekolah tersebut diperlukan langkah-langkah yang tepat salah satunya dengan melaksanakan peraturan dan tata tertib sekolah untuk mendidik peserta didik. Untuk mengurangi terjadinya pelanggaran terhadap peraturan dan tata tertib sekolah maka setiap pelanggaran akan diberikan sanksi berupa poin. Dalam pelaksanaan ketertiban sekolah di MAN 2 Barito Kuala, setiap tenaga pendidik/guru diberikan satu buku pegangan untuk mencatat pelanggaran yang dilakukan oleh peserta didik yang nantinya akan menambah poin pelanggaran peserta didik tersebut. Tentu ini memiliki suatu kekurangan dan akan menimbulkan masalah apabila nanti diperlukan perhitungan jumlah poin siswa karena harus menghitung poin dari buku pegangan semua guru tersebut dan orang tua peserta didik pun akan kesulitan untuk mengetahui pelanggaran apa saja yang telah dilakukan anaknya. sistem ini akan dibuat menggunakan berbasis web dan ditambahkan fitur SMS gateway. Dengan adanya aplikasi kredit poin terhadap pelanggaran tata tertib sekolah menggunakan SMS gateway ini diharapkan dapat membantu permasalahan pihak sekolah mengontrol peserta didiknya, serta mempermudah orang tua peserta didik untuk mengetahui informasi terbaru perkembagan anaknya melalui fitur SMS gateway.
\end{abstract}

Kata kunci : Kredit poin, Peserta Didik, Pelanggaran Peraturan Sekolah, SMS Gateway

\section{PENDAHULUAN}

Madrasah Aliyah Negeri 2 Barito Kuala adalah salah satu sekolah yang memiliki visi untuk menjadikan peserta didik yang beriman dan bertaqwa, berprestasi dan mandiri. Tentu untuk tercapainya visi sekolah tersebut diperlukan langkah-langkah yang tepat salah satunya dengan melaksanakan peraturan dan tata tertib sekolah untuk mendidik peserta didik. Namun, tidak semua anak biasa mengikuti tata tertib sekolah dengan baik seperti tidak terlambat berangkat kesekolah, tidak menggunakan seragam sesuai aturan sekolah dan peraturan lainnya.

Tentu untuk mengurangi terjadinya pelanggaran terhadap peraturan dan tata tertib sekolah maka setiap pelanggaran akan diberikan sanksi berupa poin. Poin pelanggaran yang sudah di dapat oleh peserta didik tentu akan mendapatkan konsekuensi seperti poin mencapai 30 akan dilakukan panggilan orang tua kesekolah. Dan apabila poin sudah sampai 100 peserta didik tersebut akan dikeluarkan dari sekolah.

Dalam pelaksanaan ketertiban sekolah di MAN 2 Barito Kuala, setiap tenaga pendidik/guru diberikan satu buku pegangan untuk mencatat pelanggaran yang dilakukan oleh peserta didik yang nantinya akan menambah poin pelanggaran peserta didik tersebut. Tentu ini memiliki suatu kekurangan 
dan akan menimbulkan masalah apabila nanti diperlukan perhitungan jumlah poin siswa karena harus menghitung poin dari buku pegangan semua guru tersebut.

Sistem yang masih manual yang masih berjalan di sekolah ini tentu akan memerlukan waktu yang lama apabila guru $\mathrm{BP} / \mathrm{BK}$ ingin menggumpulkan poin peserta didik tersebut. Kemudian juga, orang tua peserta didik tentu kurang mengetahui tentang poin pelanggaran yang sudah dilakukan peserta didiknya.

Untuk mengatasi permasalahan yang telah diuraikan diatas, maka peneliti melakukan penelitian dengan menerapkan teknologi yang akan membantu pihak sekolah dan juga orang tua peserta didik dengan judul "Perancangan Aplikasi Kredit Poin Siswa Menggunakan Sms Gateway".

\section{METODE PENILITIAN}

Metode penelitian yang dilakukan untuk analisis, merancang dan mengimplementasikan sistem adalah dengan menggunakan metode waterfall, melalui tahapan penelitian seperti gambar berikut:

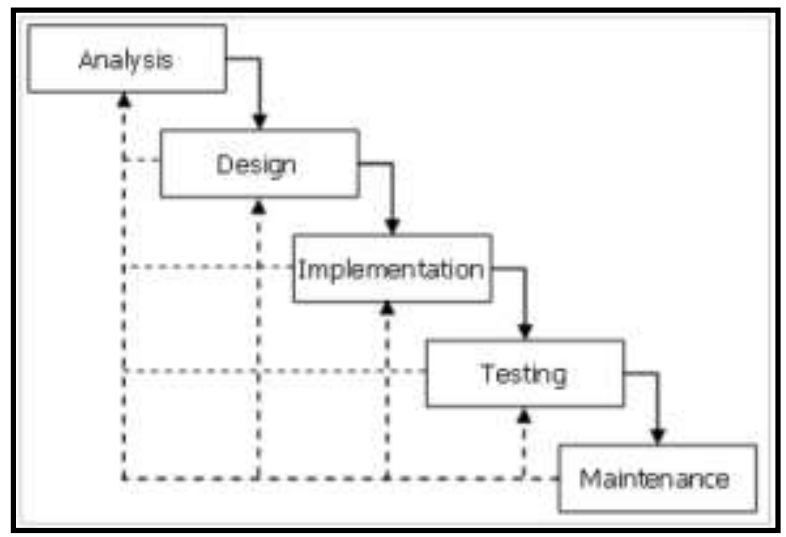

Gambar 1 Metode Waterfall

a) Analisa Sistem

Penguraian dari suatu sistem informasi yang utuh ke dalam bagian-bagian komponennya dengan maksud untuk mengidentifikasikan dan mengevaluasi permasalahan, kesempatan, hambatan yang terjadi dan kebutuhan yang diharapkan sehingga dapat diusulkan perbaikan.

Analisis sistem ini dilakukan pada saat sebelum dibuatnya perancangan sistem, biasa Jurnal Ilmiah "Technologia" dikenal dengan analisis sistem berjalan,

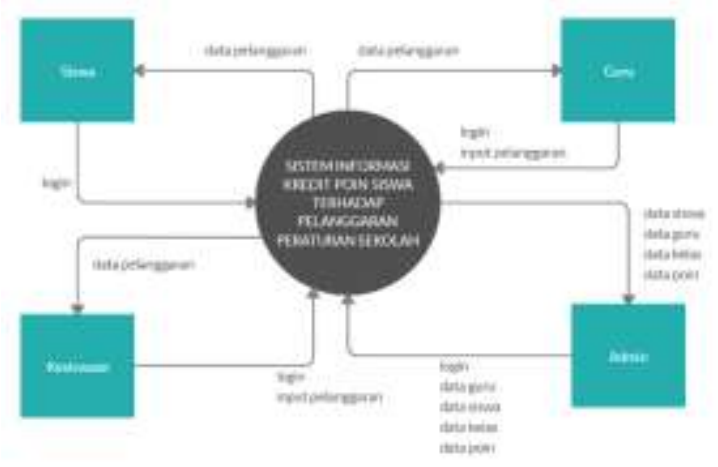

sehingga diketahui permasalan serta apa yang dibutuhkan sehingga dibuat analisis sistem usulan

b) Desain Sistem

Gambar 2. Diagram Konteks

Pada gambar 2. Merupakan alur proses sistem dimana pengguna yang terlibat dalam sistem ini terdapat 4 pengguna yaitu siswa, guru, admin dan wakil kepala sekolah bidang kesiswaan.

\section{HASIL DAN PEMBAHASAN}

Hasil dari perancangan aplikasi kredit poin siswa menggunakan SMS Gateway

a) Antarmuka Login

Halaman login merupakan tampilan awal yang muncul pertama kali saat mengakses aplikasi ini. Bagi pengguna siswa maka diminta untuk memasukkan nis sebagai username dan tanggal lahir sebagai kata sandinya. Format tanggal lahir yang harus dimasukan adalah tanggal bulan tahun tanpa spasi. Contoh bila tanggal lahir siswa adalah 23 Oktober 2002 maka kata sandi yang dimasukkan pada login adalah 23102002. Gambar 3 berikut adalah halaman login 


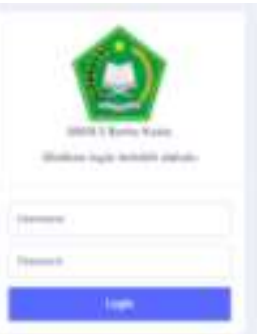

Gambar 3. Antarmuka Login

b) Antarmuka Halaman Utama

Halaman utama aplikasi terdapat 2 macam yaitu antarmuka untuk peserta didik dan antarmuka untuk guru, admin dan kesiswaan. Bagi pengguna peserta didik, antarmuka utama yang ditampilkan yaitu memberikan informasi mengenai peraturan sekolah. Sedangkan antarmuka utama selain peserta didik berisi informasi mengenai jumlah data siswa, guru, peraturan, kelas dan poin. Pada gambar 4 merupakan antarmuka untuk halaman utama peserta didik, pada gambar 5 merupakan antarmuka untuk selain peserta didik.
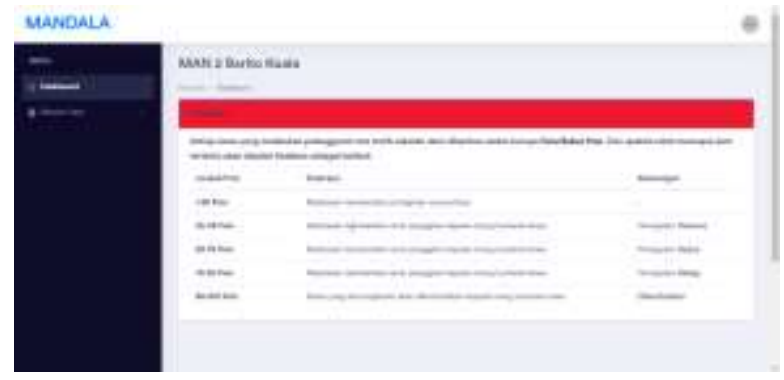

Gambar 4. Antarmuka Utama Bagi Peserta Didik



Gambar 5. Antarmuka Utama Bagi Guru

c) Antarmuka Data Poin
Halaman data poin menampilkan data tentang tata tertib sekolah yang ada di MAN 2 Barito Kuala. Halaman ini menampilkan 2 informasi yaitu tentang pelanggaran dan jumlah poin pelanggarannya. Halaman ini bisa diakses melalu menu Master Data kemudian pilih Data Poin. Berikut tampilan antarmuka data poin pada gambar 6 .

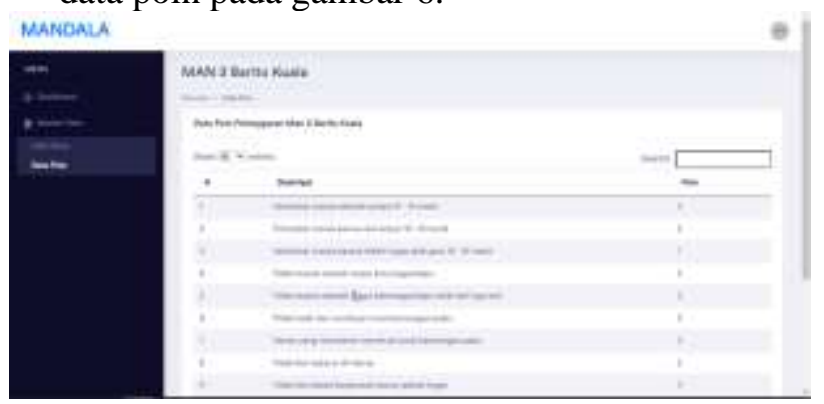

Gambar 6.Antarmuka Data Poin

d) Antarmuka Data Guru

Halaman data guru MAN 2 Barito Kuala dapat diaksed dengan memilih menu master data kemudian pilih menu Data Guru. Data guru yang ditampilkan yaitu Nip, nama lengkap guru, tempat tanggal lahir, alamat dan no telepon. Berikut tampilan halaman data guru gambar 7 .

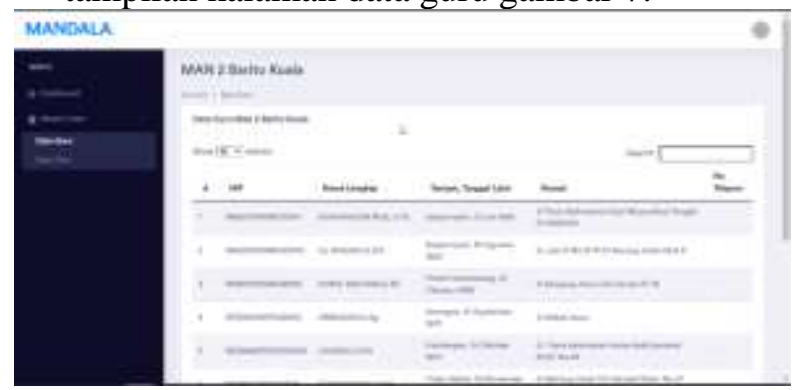

Gambar 7. Antarmuka Data Guru

e) Antarmuka Data Kelas

Halaman data kelas digunakan untuk menampilkan data kelas pada sekolah MAN 2 Barito Kuala. Pada halaman ini menampilkan nama kelas beserta jumlah siswanya. Halaman data kelas ini hanya bisa diakses bagi pengguna guru, admin dan kesiswaan. Sedangkan untuk pengguna siswa tidak ditampilkan. Halaman data kelas ini bisa diakses melalui menu master 
data kemudian pilih data kelas. Berikut tampilan halaman data kelas pada gambar 8.

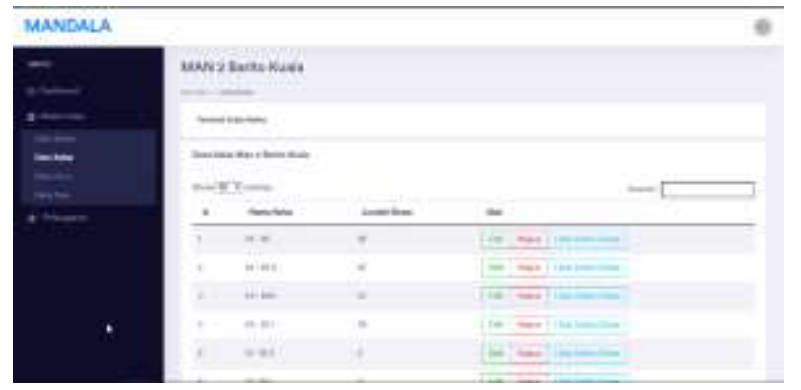

Gambar 8. Antarmuka Data Kelas

f) Antarmuka Data Siswa

Halaman data siswa ini digunakan untuk menampilkan data siswa pada sekolah MAN 2 Barito Kuala. Pada halaman ini menampilkan informasi siswa seperti NIS, nama lengkap, tempat tanggal lahir, kelas dan jumlah poin pelanggarannya. Halaman data siswa ini hanya bisa diakses bagi pengguna guru, admin dan kesiswaan. Sedangkan untuk pengguna siswa tidak ditampilkan. Halaman data siswa ini bisa diakses melalui menu master data kemudian pilih data siswa. Berikut tampilan halaman siswa pada gambar 9



Gambar 9. Antarmuka Data Siswa

g) Antarmuka Rincian Siswa

Halaman ini berisi informasi lengkap dari siswa yang telah login. Pada halaman ini menampilkan informasi pribadi siswa seperti nama, tempat tanggal lahir, nama ayah, nama ibu, no telepon orang tua dan lain-lain. Selain menampilkan informasi pribadi siswa, halaman ini juga berisi tentang data pelanggaran siswa yang pernah dilakukan oleh siswa tersebut. Halaman detail siswa ini bisa diakses Jurnal Ilmiah "Technologia" melalui data siswa pilih Detail. Berikut tampilan halaman rincian siswa pada gambar 10

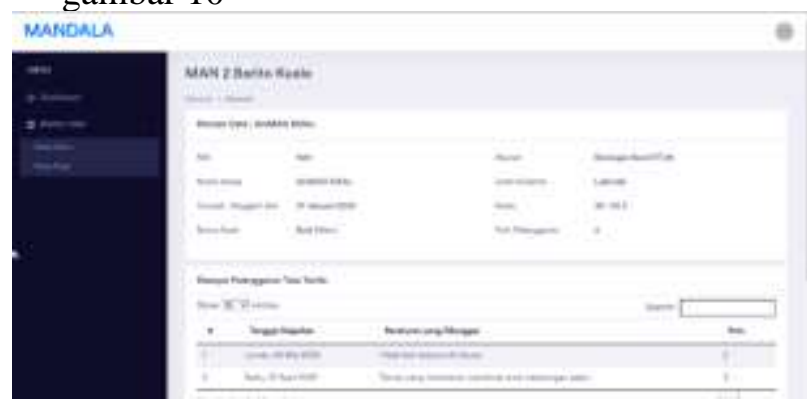

Gambar 10. Antarmuka Rincian Siswa

h) Antarmuka Data Pelanggaran

Halaman data pelanggaran ini berisi data pelanggaran tata tertib yang dilakukan olehp peserta didik. Halaman data pelanggaran ini hanya bisa diakses oleh pengguna dengan status kesiswaan dan guru. Pada halaman ini data yang ditampilkan yaitu tanggal kejadian pelanggaran, nama siswa, kelas, keterangan pelanggaran, poin pelanggarannya dan status. Selan menampilkan informasi data pelanggaran, halaman ini juga terdapat 1 buah fungsi untuk proses penambahan data pelanggaran. Berikut halaman data pelanggaran pada gambar 11 .

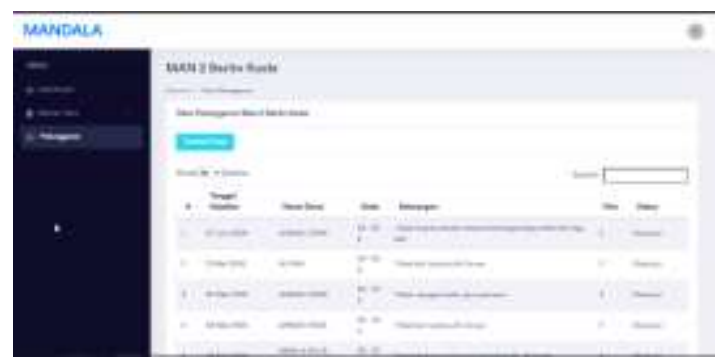

Gambar 11. Antarmuka Data Pelanggaran

i) Antarmuka Tambah Data Pelanggaran

Halaman tambah pelanggaran ini digunakan untuk proses penambahan data pelanggaran tata tertib siswa. Halaman ini hanya bisa diakses oleh pengguna dengan status guru atau kesiswaan. Pada halaman ini, untuk menambahkan data pelanggaran ada beberapa inputan yang harus diisi pengguna yaitu tanggal kejadian pelanggaran, nama siswa yang melanggar 
kemudian keterangan pelanggaran yang dilakukan oleh siswa. Kemudian klik tombol simpan untuk proses penyimpanan data pelanggaran. Berikut tampilan halaman tambah pelanggaran pada gambar 12.

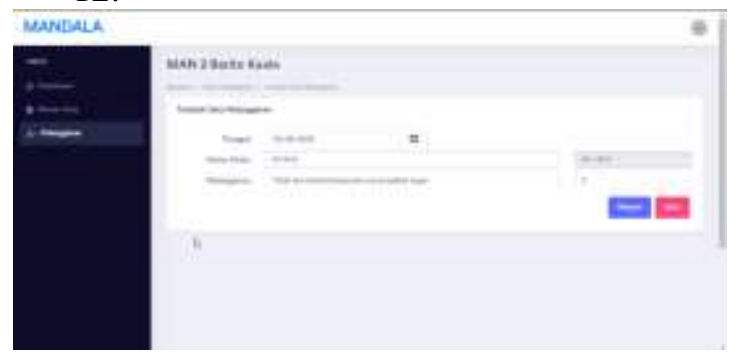

Gambar 12. Antarmuka Tambah Data Pelanggaran

j) Antarmuka Pengaturan SMS Gateway Halaman ini digunakan untuk mengatur fitur sms gateway. Pada halaman ini ada 2 pengaturan yang bisa diatur yaitu aktifkan sms gateway dan tentukan jumlah poin minimal untuk mengirimkan sms gateway. Apabila fitur sms gateway diaktifkan, maka setelah data pelanggaran disetujui oleh kesiswaan akan dikirimkan sms pemberitahuan kepada orang tua siswa yang bersangkutan karena telah melakukan pelanggaran. Berikut tampilan antarmuka pengaturan SMS Gateway pada gambar 13.

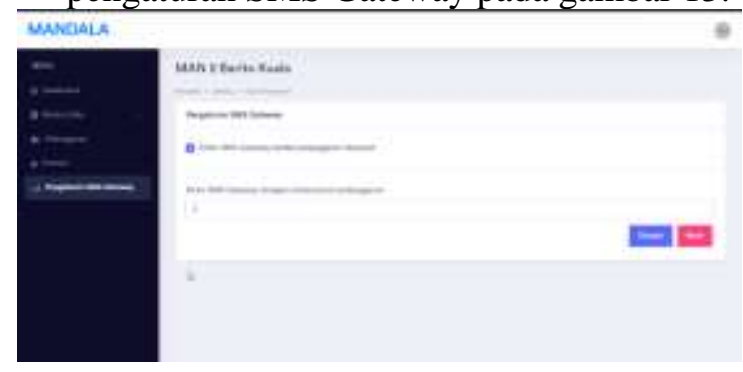

Gambar 13. Antarmuka Pengaturan SMS Gateway

k) Tampilan SMS Gateway

SMS akan terkirim pada orang tua peserta didik apabila pengaturan sms gateway diaktifkan dan poin yang diterima peserta didik memenuhi pada pengaturan sms gateway. SMS ini memberitahukan kepada orang tua bahwa peseta didik yang bersangkutan telah melakukan pelanggaran

Jurnal Ilmiah “Technologia” dan mendapatkan poin pelanggaran. Berikut tampilan sms gateway yang dikirimkan kepada orang tua peserta didik pada gambar 14 .

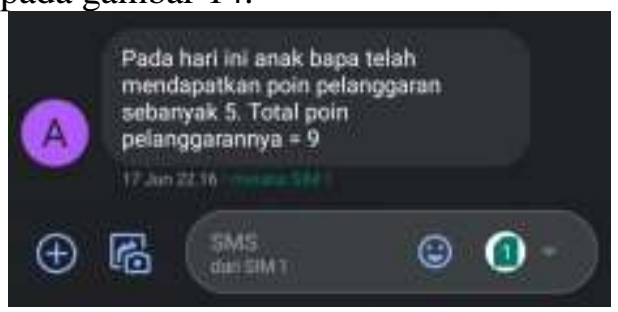

Gambar 14. Tampilan SMS Terkirim Pada Orang Tua Peserta Didik

\section{KESIMPULAN}

Dari penelitian ini, dengan adanya aplikasi perhitungan kredit poin pelanggaran peserta didik ini dapat membantu pihak sekolah khususnya wakil kepala sekolah bidang kesiswaan untuk melakukan proses perhitungan poin pelanggaran peserta didik tanpa harus menghitung manual lagi dari buku penilain peserta didik dari setiap guru. Selain itu, dengan adanya aplikasi ini orang tua peserta didik dapat mengetahui pelanggaran tata tertib yang telah dilakukan siswa yang bersangkutan.

\section{REFERENSI}

[1] Ali, Asrori. 2010. Psikologi Remaja Perkembangan Perserta Didik. Jakarta. PT. Bumi Aksara

[2] Surya, Mohamad. 2003. Psikologi Konseling. Bandung: Pustaka Bani Quraisy.

[3] Anhar. (2010). PHP dan MySQL Secara Otodidak. Jakarta: Agromedia Pustaka.

[4] Jogiyanto, \& Hartono. (2009). Analisis \& Desain Sistem Informasi. Yogyakarta: Andi Ofset.

[5] Prayitno. (2003). Wawasan dan Landasan Bimbingan Konseling. Jakarta: Depdiknas.

[6] Wahyudi, B. (2010). Perancangan Sistem. Bandung: Informatika.

[7] Safaat, Nazaruddin H, 2014, Pemrograman Aplikasi Mobile Smartphone dan Tablet PC Berbasis Android, Bandung, Informatika. 
Technologia"Vol 11, No. 4, Oktober 2020

[8] Setyawan, Dwi \& Setyo Astuti, Ely \& Ekojono. 2014. Sistem Pencatatan Poin Pelanggaran Siswa Pada SMA Negeri 1 Purwosari

Jurnal Ilmiah "Technologia" 